\title{
The Influence of Financial Resources, Human Capital, Competitive Strategy and Innovation on Business Performance Of Business Actors In Binjai City, North Sumatra
}

\author{
Linda Lores ${ }^{1}$, Retnawati Siregar ${ }^{2}$ \\ Medan University Area \\ \{lindalores0@gmail.com\}
}

\begin{abstract}
This study explores financial resources, human capital, business strategy and innovation, and the real impact on the business performance of business actors in the city of Binjai. The purpose of this study was to determine the effect of financial resources, human capital, competitive strategy, and innovation on company performance. This study focuses on business actors with more than five years of operation, with as many as 88 respondents. This research method uses Partial Least Square. The findings of the influence of financial resources, especially from third-party debt, human capital, business strategy, and innovation affect the company's performance in accordance with the theoretical literature so that it is concluded that financial resources, human capital, and innovation have a positive effect on the output and performance of the company and provide economic value. for business actors, the competitive strategy does not affect business performance.
\end{abstract}

Keywords : financial resources, human capital, product innovation

\section{Introduction}

The company's performance appraisal for management can be interpreted as an assessment of the achievements that can be achieved on the company's goals. One way is by utilizing the resources it has. Resources owned by the company consist of tangible resources and intangible resources. According to [1] that the source of competitive advantage can come from within or from within the company. RBV states that resources are valuable, rare or unique, difficult to imitate and no replacement could create a competitive advantage for the company with the basic assumption of heterogeneity and immobility that resource company that has the ability to manage resources well is believed to be able to create added value and be able to create excellence in competition by conducting innovation, research and development which will lead to an increase in company performance.

Intangible resources (Tangible assets) is a resource that is easy to be identified and evaluated. According to [2] financial resources are assets that are used to settle obligations and clear resources that the company must have available to achieve the strategy. Resource - based theory complements the strategy by focusing on the company 's efforts to accumulate assets [3] Financial resources are the main resource which is the company 's borrowing capacity and the company 's ability to generate funds internally determines its investment capacity and for the company to fund its operational activities. 
[4] results of research in Kenya stated Funding seems to be the main factor for SMEs to be able to grow since SMEs have the capacity to beat competitors, hence long-term survival in a competitive environment. B ome theories have been developed showing a number of factors that may determine the decision of the structure of the company's capital ; such as Pecking Order Theory [5]. The sequence of use of funding sources with reference to the pecking order theory according to (Kaaro, 2003) in (Saidi, 2004) is: Companies tend to use internal financing that comes from the company's retained earnings and if external funding is needed, the company will issue debt (debt) first.

Resources are not tangible (Intangible Assets) has three types of resources that belong to the intangible resources, namely: human resources, innovation and reputation. According to [6] intangible assets are: Non-monetary assets that are identifiable without physical form and are held for use in producing or delivering goods or services, rented out to other parties, or for administrative purposes. Intellectual Capital is relevant in this case because it will create added value for the business [7]. Therefore, business actors are increasingly emphasizing the importance of knowledge assets as a form of intangible asset.

[8] [9] examined the relationship between HR planning with business performance and found no correlation among them now more prove a positive and significant correlation between human capital and corporate performance studies [10] examine the relationship between human capital and corporate performance $d$ ith estimation of performance, there is a very strong relationship between HR and productivity and financial performance. According to [11 ] human capital has a positive but not significant effect on the performance of SMEs Cluster Handycraft in Semarang City . [12 ] The company realizes that the profits obtained by the company actually come from human capital, do not view the company's activities more from a business perspective.

According to studies such as [13][14 ] found innovation as one of the significant outputs of intellectual capital. According to [15] stated that increasing the level of innovation improves financial performance, with the relevance of innovations developed to meet customer needs and innovations developed to differentiate from competitors can improve financial performance. And the results show that in SMEs the level of technology adopted to develop innovation has no impact on financial performance. Business actors who adopt innovative technology for use in business operations cannot help their business growth.

One of the sectors in which small and medium enterprises are very likely to be developed is the creative industry. (Director of Bank Indonesia Sumatra, Andiwiana S ) said that the contribution of UM KM to GDP is quite significant, amounting to $55.56 \%$ of the total GDP (national data). For a number of SMEs in North Sumatra reached 2,8 million and the number of SMEs registered and verified at the Department of Cooperatives and SMEs simply amounting to 380249 business units . [16]. It is time for SMEs to "Go Digital, to face competition, the decline in the number of business units is due to the inability of SMEs to face competition.

Opportunities and challenges must not only be faced but also must be carried out in accordance with the development of time, the entry of the industrial era 4.0 has an impact especially on business ventures. Businesses must be prepared to face this development if they do not want to be left far behind. Industry 4.0 is not just a digital and internet change that occurred in the 3.0 revolution, but rather integrates technology and artificial intelligence.

The impact of industry 4.0 is very large for the business sector, which is better known as the era of disrupting human life. Where fast companies will crush slow companies. So small businesses must be able to think and act faster, meaning the ability of businesses to quickly 
adapt and innovate. The strategy used to face the industrial era 4.0. Business actors must create superior strategies in order to compete. In addition to that, businesses are still facing problems related to the business climate, such as: (a) the amount of the transaction costs, the length of the permitting process and the emergence of various charges; and (b) unhealthy business practices.

Choice of strategies and policies to empower businesses in entering global market era is essential to guarantee the survival and development of $U$ saha, as an employer, a source of growth and income distribution. The above phenomenon becomes a challenge as well as an opportunity for every businessperson starting from basic strategies to routine activities. Facing the challenge of how businesses can survive and advance, is none other than we must be innovative, to be able to compete in the competition in industry 4.0. Problems that arise from sources of business capital, human resources, strategies carried out in developing innovation will be able to accelerate the economy of businesspeople in facing the industrial era 4.0.
Formulation of the problem:
a. Do financial resources affect business performance?
b. Does Human Capital affect business performance?
c. Does competitive strategy affect business performance?
d. Does Innovation Affect Business Performance?

\section{Literature Review}

\subsection{Stakeholder Theory}

Stakeholder theory [ 17 ] argues that all stakeholders have the right to be treated fairly and managers should manage the organization for the benefit of all stakeholders. In the context of explaining the concept of Intellectual capital (IC) or intellectual capital, stakeholder theory can be viewed from two fields, namely the field of ethics and the field of managerial. The field of ethics argues that all stakeholders have the right to be treated fairly by the organization and managers should manage the organization for the benefit of all stakeholders.

Value creation in this context is by utilizing all the potential of the company, both employees (human capital), physical assets (physical capital), and structural capital . Stakeholders are "groups or individuals with whom the organization interacts or have interdependence" and "any individual or group who can influence or be influenced by the actions, decisions, policies, practices or goals of the organization [18 ][ 19].

\subsection{Resource Based Theory}

The Resource-Based View (RBV) approach states that companies can achieve sustainable competitive advantage and gain superior profits by owning or controlling strategic assets, both tangible and intangible. Resource-based theory is defined as an economic tool to translate strategic resources in accordance with the company, so that in principle it is seen as the basis for determining the company's competitive advantage in applying a set of valuable resources for the company [ 20 ].

\subsection{Human Capital}


Some expert opinions such as:[21] state that there are three elements of intangible assets, namely: human capital, customer capital, and structural/organizational capital [22 ] which states that there are three elements of intangible assets, namely: human capital, structural capital and customer capital This is clarified by [23 ] which states that human capital is knowledge, competence, attitude, health, and characteristics possessed by humans.

\subsection{Business Performance}

According to [24] Performance is strongly influenced by the ability, motivation, enthusiasm and expectations of each individual towards a person, group and company. Performance emphasizes the efficiency of saving the use of available resources to achieve the desired goals. In other words, performance is the productivity of a person, group or company, performance is declared good and successful if the desired goals both by individuals, groups and companies can be achieved properly. The indicators used [25] [26] are sales growth, profit growth, capital growth consisting of sales growth, business profit growth.

\subsection{Innovation}

Innovation will assist management in achieving better performance for business continuity and sustainability so that it runs in accordance with company goals, supported by innovation capabilities consisting of ideas, new products and others. [27] The products are supplied to potential users, new or significantly changed in relation to the characteristics or usage. [2 8 ] [29] The process of innovation that resulted in demand for a product, "elements introduced into the material production operation or service organization, task specifications, work mechanisms and information flow, and equipment used to produce products or provide services with the aim of achieving lower costs and/or higher product quality .

\section{Research methods}

\subsection{Types and sources of data}

The type of data used is quantitative data. Quantitative data is in the form of information or explanation expressed in numbers or in the form of numbers [ 30$]$.

\subsection{Population and Research Sample}

The population is the entire set of elements that we can use as a basis for making some conclusions. The research population is all businesspeople in Binjai City. by distributing questionnaires. The returned questionnaire was used as a sample.

\subsection{Data Collection Techniques}

Collecting data in this study in the form of primary data derived from the answers to questionnaires distributed to all SMEs using a Likert scale with 5 rating scales:
a. Strongly disagree, given a weight of 1
b. Disagree is given a weight of 2
c. Slightly disagree, given a weight of 3
d. Neutral, weighted 4
e. Slightly agree, given a weight of 5
f. Agree, given a weight of 6
g. Strongly agree, given a weight of 7 


\subsection{Data Analysis Techniques and Hypothesis Testing}

The method of forming indicator variables is using the ratio method of the research variable indicators. Data analysis in this study used the Partial Least Square (PLS) method. PLS can be used on any type of data scale (nominal, ordinal, interval, ratio ) as well as more flexible assumption requirements. PLS is also used to measure the relationship of each indicator to its construct. In addition, in PLS , bootstrapping tests can be carried out on structural models that are outer models and inner models.

Because in this study using indicators to measure each construct, and also the measurement model is structural, it was decided to use PLS. But PLS prioritizes exploration rather than confirmation. However, the main purpose of PLS is to explain the relationships between constructs and emphasize the notion of the value of these relationships. In this case, the important thing that must be considered is the necessity of a theory that provides assumptions to describe the model, variable selection, analytical approach, and interpretation of the results.

\section{Results and Discussion}

\subsection{Research results}

This study used 88 respondents. By distributing questionnaires to business actors in the city of Binjai, 140 questionnaires were distributed. and who returned 98 questionnaires and those who met the requirements used as many as 88 appropriate questionnaires.

\section{Structural Model Design (Inner Model)}

Description of latent variables and their manifest variables are as follows:

a. Latent variable exogenous sources d aya financially $(\mathrm{X} 1)$ has eight variables manifest (indicators) are expressed by X1 . 1; up to X1.8

b. The exogenous latent variable Human Capital (X2) has seven manifest variables (indicators), namely X2.1 to X2.7.

c. Exogenous latent variables Competitive strategy (X3) has 6 manifest variables (indicators) expressed by X3.1 to X3.6

d. Innovation endogenous latent variable (X4) has five manifest variables (indicators) expressed by X4.1 to X4. 5

e. Endogenous latent variable Business performance (Y) has 6 manifest variables (indicators) expressed by $\mathrm{Y} 1$ to $\mathrm{Y} 6$

When evaluating the measurement model for business respondents in Binjai City, the indicators used are not entirely valid and reliable. So that the appropriate structural model for this research is obtained, namely as follows : 


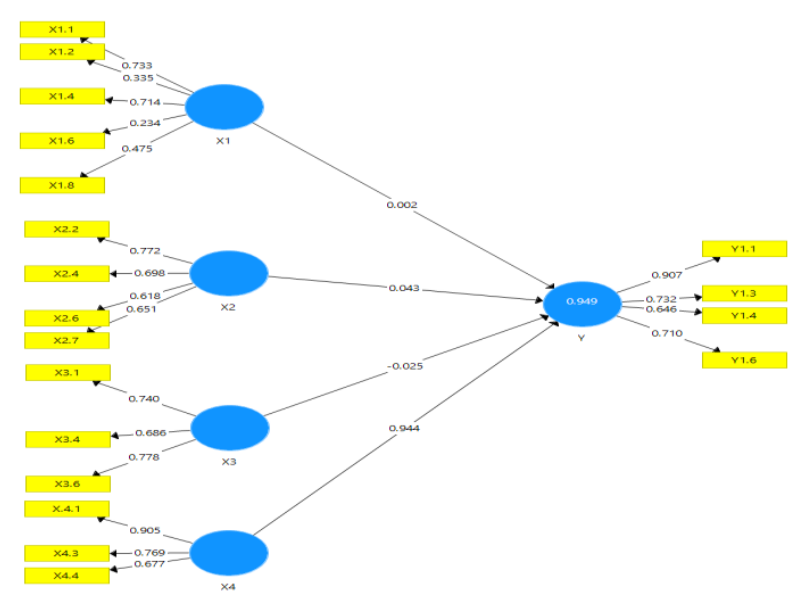

Fig 1. Output Loading Factor Modeling Source: processed primary data output

\section{Measurement Model Evaluation (Outer ModeI)}

The evaluation of the measurement model consists of three stages, namely the convergent validity test, the discriminant validity test and the composite reliability test.

\section{Convergent Validity Test}

Testing the validity of reflective indicators can be done by using the correlation between indicator scores and construct scores. Measurements with reflective indicators show that there is a change in an indicator in a construct when other indicators in the same construct change. The following are the results of calculations using the PLS 3.0 smart computer program:

\begin{tabular}{|c|c|c|c|c|c|}
\hline & $\begin{array}{l}\text { Financial } \\
\text { resource }\end{array}$ & Human Capital & $\begin{array}{l}\text { Competitive } \\
\text { Strategy }\end{array}$ & Innovation & $\begin{array}{l}\text { Business } \\
\text { Performance }\end{array}$ \\
\hline & $\mathrm{X} 1$ & $\mathrm{X} 2$ & $\mathrm{X} 3$ & $\mathrm{X} 4$ & $\mathrm{Y}$ \\
\hline $\mathrm{X} 1.1$ & 0,733 & & & & \\
\hline $\mathrm{X} 1.2$ & $0,73.5$ & & & & \\
\hline $\mathrm{X} 1.4$ & 0.714 & & & & \\
\hline $\mathrm{X} 1.6$ & 0.734 & & & & \\
\hline $\mathrm{X} 1.8$ & 0,709 & & & & \\
\hline $\mathrm{X} 2.2$ & & 0,772 & & & \\
\hline $\mathrm{X} 2.4$ & & 0,689 & & & \\
\hline $\mathrm{X} 2.6$ & & 0,618 & & & \\
\hline $\mathrm{X} 2.7$ & & $0,6.51$ & & & \\
\hline $\mathrm{X} 3.1$ & & & 0,740 & & \\
\hline X3.4 & & & 0,686 & & \\
\hline X3.6 & & & 0,778 & & \\
\hline $\mathrm{X} 4.1$ & & & & $0,90.5$ & \\
\hline & & & & & \\
\hline X4.3 & & & & 0,769 & \\
\hline
\end{tabular}




\begin{tabular}{|l|l|l|l|l|l|}
\hline X4.4 & & & & 0,677 & \\
\hline Y1 & & & & & 0,907 \\
\hline Y3 & & & & & 0,732 \\
\hline Y4 & & & & & 0,648 \\
\hline Y6 & & & & & 0,710 \\
\hline
\end{tabular}

The researcher uses a loading value $>0,5,[31]$ a correlation can be said to meet convergent validity if it has a loading value of greater than 0.5 . The output shows that the loading factor gives a value above the recommended value, so the indicators used in this study have met convergent validity. Because the AVE root value of the three research variables is greater than the correlation value between variables, it can be said that the variables in this study have good discriminant validity . ( see picture 2 )

\section{Reliability Test}

The reliability test in this study used two measures, namely Cronbach's Alpha and Composite Reliability. This value reflects the reliability of all indicators in the model. The magnitude of a minimum value is 0,7 . In addition to Cronbach's Alpha, the Composite Reliability value must be above 0.60

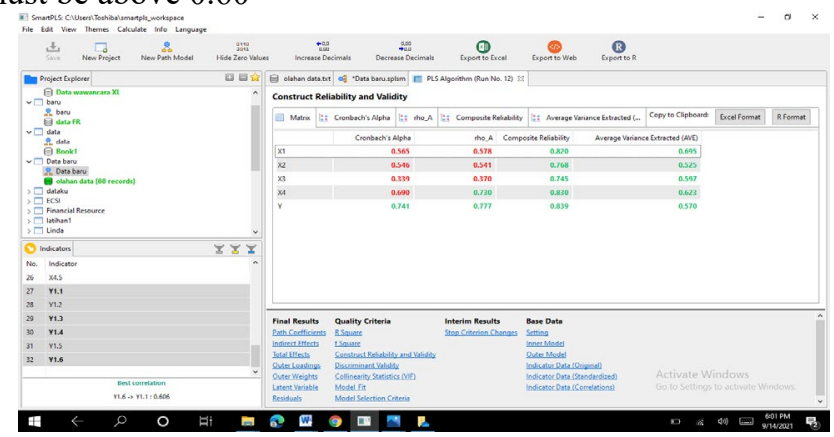

Fig 2. Reliability Test Results (Source: PLS 2021)

Based on Figure 2 above, it can be seen that the Cronbach's Alpha and Composite Reliability values for all variables in this study have met the established criteria so that it can be said that the variables in this study are reliable.

\section{Evaluation of the Structural Model (Inner Model)}

Evaluation of the structural model on SEM with PLS was carried out by performing the Rquared $\left(\mathrm{R}^{2}\right)$ test and the $\mathrm{m}$ significance test using the smartPLS 3.0 computer program obtained: 


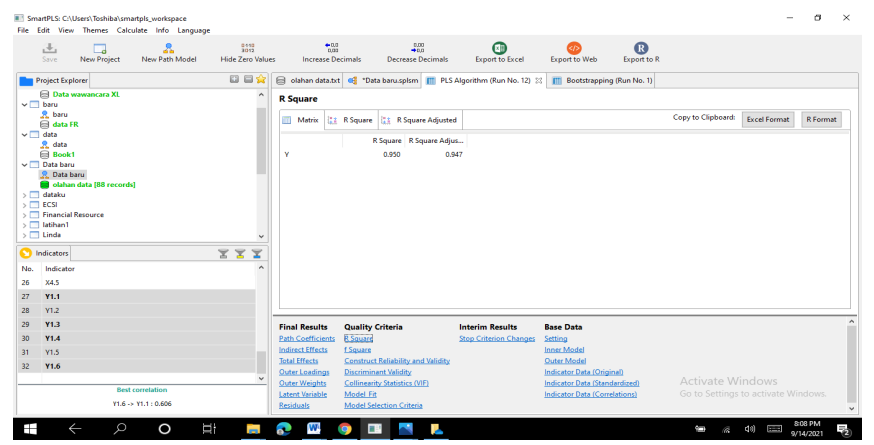

Fig 3. $R^{2}$. Calculation Output (Source: Processed primary data output, 2021)

The value of R-squared $\left(\mathrm{R}^{2}\right)$ is used to measure how much influence certain independent latent variables have on the dependent latent variable. [31], the results of $\mathrm{R}^{2}$ by 0,67 indicate that the models are categorized either. Table 4.15 shows the R2 value of this study of 0.947 , which means it has a value greater than 0.67 . So it can be said that the model formed is categorized as a good model.

\section{Significance Test}

The significance test on the SEM model with PLS aims to determine the effect of exogenous variables on endogenous variables. Hypothesis testing with the PLS SEM method is carried out by performing a bootstrapping process with the help of the smartPLS 3.0 computer program so that the relationship between the influence of exogenous variables on endogenous variables is as follows:

Table 2. Calculation Results of Research Data Bootstrapping

\begin{tabular}{|l|l|l|l|l|l|}
\hline & $\begin{array}{l}\text { Original } \\
\text { Sample } \\
\text { Estimate (O) }\end{array}$ & $\begin{array}{l}\text { Sample } \\
\text { Mean } \\
(\mathrm{M})\end{array}$ & $\begin{array}{l}\text { Standard } \\
\text { Deviation } \\
(\mathrm{STD})\end{array}$ & $\begin{array}{l}\text { T Statistics } \\
\text { (IO/STDE } \\
\text { VI) }\end{array}$ & P Values \\
\hline $\mathrm{X} 1->\mathrm{Y}$ & 0.473 & 0.467 & 0.069 & 6.903 & 0.014 \\
\hline $\mathrm{X} 2->\mathrm{Y}$ & 0.403 & 0.420 & 0.103 & 4.126 & 0.043 \\
\hline $\mathrm{X} 3->\mathrm{Y}$ & 0,078 & 0,121 & 0,078 & 1,379 & 0,716 \\
\hline $\mathrm{X} 4->\mathrm{Y}$ & 0,839 & 0,927 & 0,030 & 3,673 & 0,000 \\
\hline
\end{tabular}

Source: primary data output processed, 2021

a. The effect of financial resources on business performance (H1) is indicated by the coefficient, the t-statistics value of 6.903 and greater than the t-table value of 1.980 and the p-value of 0.014 which means it is smaller than 0.05 . Thus H1 can be proven to be accepted.. The positive value of the beta coefficient indicates that the relationship between the two is positive. That is, more have financial resources sufficient then it will be better productivity efforts towards business performance businesses in the town of Binjai.

b. Hypothesis Testing Var iabel Human capital (X2) to variable business performance (Y)

The influence of human capital on business performance (H 2 ) the value of $\mathrm{t}$ statistics for 4,126 LEB ih greater than 1,980 t-table value, and the value of $p$ value of 0.043 , which means less than 0.05 . Thus, the hypothesis $\mathrm{H} 2$ can be proven and accepted, the value of the beta coefficient is positive indicating that the relationship 
between the two is positive. This means that the higher the human capital, it will be the higher the level of business performance .

c. Hypothesis Testing Competitive strategy variable (X3) on business performance variable (Y)

Effect of competitive strategy on the performance of the business (H3) value of 1,379 t-statistics greater than 1,980 t-table value, and the value of $p$ value of 0.716 , which means larger than 0,05 . Thus, the hypothesis $\mathrm{H} 3$ can be proven, the value of beta coefficient is positive indicates that the relationship between the two is positive. This means that the more you have a competitive strategy in your business, the higher the level of business performance will be. Innovation Variable Hypothesis Testing (X3) on Business Performance Variables (Y). The effect of competitive strategy on business performance (H3), the t-statistics value of 1.379 is smaller than the $\mathrm{t}$-table value of 1.980 , and the p-value of 0.716 which means it is greater than 0.05 . Thus the hypothesis $\mathrm{H} 3$ is rejected, does not meet the requirements. This means that the competitive strategy in its business does not affect the level of business performance.

\subsection{Discussion}

This study has five variables, namely financial resources, human capital, competitive strategy, innovation and business performance. In the results of the hypothesis test, the results were found, where $\mathrm{H} 1, \mathrm{H} 2, \mathrm{H} 4$ had a significant and positive effect on $\mathrm{Y}$, while $\mathrm{H} 3$ was rejected or said that $\mathrm{H} 3$ had no effect on business performance. Financial resources are proven to affect business performance, before doing business, businesspeople need initial business capital, which can come from anywhere, including own capital, debt, external investment. In business operations that are already running, they can earn profits, which is one source of business capital, then short-term debt and long-term debt.

Most business actors obtain their source of business capital from operating profits. If business actors require additional capital, business actors make loans to safer banks. Financial resources that are quite good are able to contribute to business performance, this is supported by all the expertise, skills, knowledge, and creativity of business actors which can be realized in a work ability that can be used to produce a professional service, created innovation and economic value high.

A strategy is also needed to apply work skills. Would however Strategies Competing are using cost advantages are felt not to be appropriate to use. This is also in accordance with the statistical results. Competitive Strategy has no effect on business performance. And it takes another strategy that is more appropriate to improve business performance which is supported by various strategies such as a differential strategy or a focus strategy.

\section{Conclusions and Suggestions}

Based on these results, the suggestions can be given, among others: the expected businesses also consider in the selection of sources of capital has to offer third party in consideration of financial capability, so as to maintain business continuity. Allocating the work ability of the workforce in one asset that must be maintained with loyalty because the creation of an innovation mostly comes from a creative workforce. And create and use the 
right business strategy with the type of business. The suggestions related to this research are for further research to use competitive strategy indicators that are more focused.

\section{References}

[1] Barney,Jay,: Firm resource and Sustained Competitive Adventage. Jurnal of management , 17:99120.(1991)

[2] Stacey,R, : Strategi Management and Organitational Dynamics: The Callenge of complexity. Boston,MA: Person Education Company.(2011)

[3] Degrevel,D, : Strategy as Practice to Reconcile Small Busineses Strategies and RBV? Journal of Management Policy and Practice, 13,44-46, Retrived from http://www.jmppnet.com. (2012)

[4] Priscilla Nyanchama Ombongi, Wei Long, : Factors Affecting Financial Performance of Small and Medium Enterprises (SMEs): A Case of Manufacturing SMEs in Kenya. International Journal of Research in Business Studies and Management , pp 37-45.(2018)

[5] Donaldson G, : Corporate debt capacity : a study of corporate debt policy and the determination of corporate debt capacity. Boston: Graduate school of Business Administration Harvard University .(1996)

[6] Ikatan Akuntansi Indonesia. PSAK No. 1 Tentang Laporan Keuangan- edisi revisi 2015. Penerbit Dewan Standar Akuntansi Keuangan: PT. Raja Grafindo, (2015)

[7] Hedberg, Anna \& Stenius-Bratt, Hedvig,: Intellectual Capital Management in the Creative Industries, Thesis, Center for Intellectual Property Studies, Chalmers University of Technology, Goteborg University, Sweden. Tersedia di http://gupea. ub.gu.se/bitstream/2077/1890/1/200637. Pdf (2006).

[8] Nkomo, S.M, : Human resource planning and organisational performance: An exploratory analysis. Strategic Management Journal, 8: 387-392. (1987)

[9] Delaney, Lewin, and Ichniowski, C, : Human resource management policies and practices in American firms. New York: Industrial Relations Research Centre, Graduate School of Columbia University.(1988)

[10 Guest, D.E., Michie, J, Conway, N \& Sheehan, M, : Human resource management and corporate performance in the UK. British Journal of Industrial Relations, 41:291-314.(2003)

[11] Maya Indriastuti Dista Amalia Arifah, : Peningkatan Kinerja Ukm Dengan Pengelolaan Intellectual Capital Dan Inovasi , CBAM-FEUnissula, Pp 649 - 661. (2012)

[12] Endri, : Peran Human Capital Dalam Meningkatkan Kinerja Perusahaan: Suatu Tinjauan Teoritis Dan Empiris ABFI Institute Perbanas.(2011)

[13] Muammer Zerenler Selcuk Burak Hasiloglu,Mete Sezgin, : Intellectual Capital and Innovation Performance:Empirical Evidence in the Turkish Automotive Supplier. Journal of Technology management and Innovation, Vol.3 Issues .4, pp.31-34.(2008).

[14] Wu,WY,Chang, ML and Chen CW, : Promoting Innovation through the accumulation of Intellectual Capital, social capital and entrepreneurial orientation. R\& D Management, Vol.38 No 3 pp. 265-277.(2008)

[15] Barbara Bigliardi, : The effect of innovation on financial performance: A research study involving SME's. organotation \& Management ,pp. 245-255, (2013).

[16] ( https://www.wartaekonomi) Direktur Bank Indonesia

[17] Freeman R.E, : Strategic Management : A Stakeholder Approach . Boston: Ballinger.(1984)

[18] Carroll, : Ethnics and Stakeholder Management. In A. Carroll, Business and Society . South Western: Cincinnati. pp.60.(1993).

[19] Donaldson, T and L.E.Preston, : Concepts, Evidence, and Imlication. In T. a. Donaldson, The Stakeholder Theory Of Corporation, Academy Of Management Review. (Pp. 20(10,65-91. (1995).

[20] Kaaro, Hermeindito, : Analisis Leverage Dan Dividen Dalam Lingkungan Ketidakpastian: Pendekatan Pecking Order Theory dan Balancing Theory. Jurnal Ekonomi dan Bisnis. Universitas Teknologi Yogyakarta (9), September- Desember, Pp.423-444.(2003)

[21] Barney,Jay, : Firm resource and Sustained Competitive Adventage. Jurnal of management , 17:99120.(1991)

[22] Andriessen, D.\&Tissen, R, : Weightless Wealth: Finding Your Real Value in a Future of Intangible Assets. London: Financial Times/Prentice Hall.(2000) 
[23] Bontis, N. and Fitz-enz, J, : Intellectual capital ROI: A Causal Map of Human Capital Antecedents and Consequent, Journal of Intellectual Capital, Vol. 3 No. 3, pp. 223-47.(2002).

[24] P.N. Rastogi , : Knowledge management and intellectual capital as a paradigm of value creation (2002).

[25] Theo Suhardi, : Entrepreneurship, UNPAD PRESS. (2012).

[26] Endi Sarwoko,Surachman, Armanu and Djumilah Hadiwidjojo, : Entrepreneurial Characteristics and Competency as Determinants of Business Performance in SMEs. Journal of Business and Management. Volume 7, Issue 3, Pp.31-38. (2013).

[27] Lee. D.Y. and Tsang E.W.K. : The Effect Of Entrepreneurial Personality, Background and Network Activities On Venture Growth, Journal Of Management Studies. 38 - 4 pp 583 - 602.(2001)

[28] Bergfors, M. E., \& Larsson, A, : Product and process innovation in process industry a new innovation perspective on development. Journal of Strategy and Management, 2(3), Pp. 261-276, (2009). [29] Hatch, N. W., \& Mowery, D. C, : Process Innovation and Learning by Doing in Semiconductor Manufacturing. management science.(1998),

[30] Uma Sekaran, : Research Methods For Business (Metode Penelitian Untuk Bisnis). Jakarta: Salemba Empat. (2011)

[31] Ghozali, Imam, : Aplikasi Analisis Multivariate Dengan Program SPSS ,Edisi Ketiga, Badan Penerbit Universitas Diponegoro, Semarang. (2005). 